\title{
Are Transitions a Sufficient Goal for ABE Students or Programs?
}

\author{
Bob Hughes, Seattle University, and Christine Knighton, Highline College
}

Reading the Federal Register announcement (U.S. Department of Education, 2016) of Title II of the Workforce Innovation and Opportunity Act (WIOA) offers a glimpse of WIOA's priorities. These priorities are important because they drive funding allocations for adult basic education in the nation; and that funding, in turn, determines how funded programs operate in order to receive that funding. As the largest funder of adult basic education $(\mathrm{ABE})$ in the nation, providing over $\$ 600$ million through its Basic Grants to States (U.S. Department of Education, 2019), WIOA drives $\mathrm{ABE}$ policies and practices.

A review of the announcement on Title II shows how much the concept of transitioning beyond basic skills has become critical. The phrase "transition to" is repeated 46 times throughout the document and is clarified with language that brings the importance of transitions to the forefront. Basic skills learners attend classes not as an end, but rather as a point that takes them forward to something else, as noted in this explanation:

WIOA retains and expands the purposes of AEFLA [Adult Education and Family Literacy Act]. Under WIA [the legislation that WIOA supersedes], AEFLA aimed to help adults improve their educational and employment outcomes, become self-sufficient, and support the educational development of their children. Under WIOA, AEFLA's purposes have been expanded to include assisting adults to transition to postsecondary education and training, including through career pathway programs. Further, WIOA formalizes the role of adult education in assisting English language learners to acquire the skills needed to succeed in the 21st- century economy. (U.S. Department of Education, 2016, Subpart A-Adult Education General Provisions 463.1, p. 55529)

The shift described above should not be overlooked. The unapologetic emphasis is on education for learners' economic gains. While WIOA-funded ABE can support parenting development, civic engagement, and other ancillary outcomes, transitions for economic impact provides a significant focus. Basic skills have become primarily about "transitioning to" to benefit learners' career and economic needs.

The connection between literacy and employment is not new, however. As Bannon (2016) shows in her analysis of adult literacy in the 1960s, the Adult Education Act (part of Title III of the Elementary and Secondary Education Act) was passed into law in 1966 as a follow up to the 1964 Economic Opportunity Act, and it was connected to Lyndon Johnson's War on Poverty. She argues that during this era, the notion of literacy for economic benefit gained hold as the idea of literacy as "capital" became more entrenched in the thinking and policies that accepted that: 
An individual's character is defined by that person's possession of the abilities to read and write. Literacy is capital, a marker of status, as are cars, clothes, and other material goods that signify one's economic standing. Illiteracy, by contrast, signifies little education, poverty, low-paid work, all of which in turn signify immorality, bad citizenship, and dependence. (Bannon, 2016, p. 319)

Much of what now exists has evolved into commonly accepted and believed values that now define policies and practices. Over the past 25 years, especially, that evolution has been driven by adoption of national and state standards that changed focus. As recently as 2000, though, there was a more complex purpose for basic skills beyond being a springboard for employment and economic advancement. At that time, the Equipped for the Future (EFF) Content Standards of 2000 formed the basis for many state standards that were used to establish policies and practices during the first decade of this current century. In the 2001 publication of those standards that are subtitled "What Adults Need to Know and Be Able to Do in the 21st Century" (Stein, 2001), the authors describe a 6-year process for developing those standards. The process engaged over 1,100 stakeholders that included practitioners, employers, academics, and policy makers to design the four skill areas of the EFF Content Standards:

1. Communication Skills

2. Decision-Making Skills

3. Interpersonal Skills

4. Lifelong Learning Skills (Stein, 2001, p. 17)

As a lengthy document outlining the standards for each of these skills areas, the EFF Content Standards explicate how each skill is developed and measured. The authors note that:

EFF will enable the field to expand what can be measured so that programs can demonstrate how they systematically contribute to achieving all three purposes of the Adult Education and Family Literacy Act-to assist adults in 'obtaining the knowledge and skills necessary for employment and self-sufficiency' and in 'the completion of secondary school education,' and to assist 'parents in obtaining the skills necessary to be full partners in their children's educational development.' (Stein, 2001, p. 64)

These four skill areas and three purposes made the EFF Content Standards an ambitious and holistic touchstone for ABE. While employment is considered as an outcome in the EFF Content Standards, it is connected to one outcome among three. The phrase "transition to" is only used twice in the document: once in a warning to adult basic skills providers and policy makers of the needed supports required in the transition process, and once in a standard that requires learners to to use their “... skills and strengths in new ways to transition to other jobs or careers" (Stein, 2001, p. 143).

In his analysis of conflicting epistemological perspectives in ABE, Demetrion (2005) devotes a chapter to the challenges that the EFF Content standards faced in the early 2000s as the dominant federal policy requiring empirically based analyses of impact ran against the more holistic view of growth and development espoused by the EFF Content Standards. The U.S. Department of Education at the time emphasized a need for showing quantitatively based results in all its programs, specifically through the National Reporting System (NRS), which began operations in 1999 (American Institutes for Research, 2019). For the federal government to fund and to support any efforts, they required clear and observable outcomes. As Sticht (2008) notes, those outcomes were muddied as NRS began because of how they were gathered and reported nationally; however, the reliance on quantitative outcome measures was clear. The focus on transitions as a measurable outcome of $\mathrm{ABE}$ efforts grew from that emphasis on measurement. "Transition to" provides markers 
for success and provides a purpose much less encumbered than the complexity attempted by the EFF Content Standards. Additionally, "transition to" offers a close connection to policies that emphasize the importance of basic skills for employment.

In the past decade, states focused less on the EFF Content Standards than on standards that support transitions beyond basic skills. States now look elsewhere to find a footing that supports the federal funding mandates that emphasize employment pathways. Most significantly, the College and Career Readiness Standards (Pimentel, 2013) have gained ascendancy as the U.S. Department of Education has encouraged states to see those as a bridge between the Common Core Standards in K-12 schools and education beyond secondary schooling. The department's online explanation is that, "The integration of College and Career Readiness standards into adult education programs is intended to provide all adult students with the opportunity to be prepared for postsecondary training without needing remediation" (Literacy Information and Communication System, 2019).

The U. S. Department of Education offers evidence to support the value of "transitions to" as a focus of basic skills. In a 2012 report, the U.S. Department of Education Office of Vocational and Adult Education (2012) identified three "bridge" programs that assist basic skills students transition beyond basic skills. That report highlights the low numbers of typical basic skills students who matriculate beyond basic skills and provides evidence of the positive impact of these three programs in addressing that lack of transition in other programs. Citing two studies conducted by Jenkins, Zeidenberg, and Kienzl (2009) and Zeidenberg, Cho, and Jenkins (2010) of the I-BEST program in Washington state, the report concludes that, "Findings suggested that being enrolled in a college that offered I-BEST increased the likelihood that basic skills students would earn college credit and receive an occupational certificate within three years" (U.S. Department of Education Office of Vocational and Adult Education, 2012, p. 6). Similarly, the report cites Alamprese's then emerging research that was published 2 years later (Alamprese, 2014), which found in the Oregon Pathways for Adult Basic Skills Transition to Education and Work project, “...adults participating in OPABS academically enhanced basic skills courses identify a career path, develop their basic skills, and transition to postsecondary transfer-credit courses at the same or faster rates as adults in non-OPABS courses" (U.S. Department of Education Office of Vocational and Adult Education, 2012, p.7). Finally, the report shows findings from the Illinois Adult Education Bridge Initiative of which a study by Taylor and Bragg (2012) showed positive gains in NRS skills levels.

So, the nation has come to a point where "transition to" forms a basis for how it offers basic skills for adult learners. Is that bad? After all, in expending the relatively few dollars that federal and state budgets provide for adult education, should the nation not seek to look at the most impact for those dollars? Moreover, is economic impact a serious enough need to focus those resources? The arguments suggested by these questions are compelling. Since the 1996 welfare reform act, especially, we see much of the education that is aimed at poor adults focused on jobs and employment to get these adults off public assistance and into economic self-sufficiency. If the nation gets more skilled workers and provides more opportunities for those workers, is that not the best outcome for both the adults and the society?

The issue is not that $\mathrm{ABE}$ focusing on "transitions to" for economic gain is bad. The conversation that 
has been lost is the question of what is missing. In not interrogating this often-singular purpose, we miss other potential purposes. The evolution described above often subsumes or supplants other purposes. By the mid-1990s, ABE had matured to the point where it was exploring those potentials, as evidenced by the EFF Content Standards.

What has come since is not "wrong" as much as it is incomplete. As the field has followed federal mandates to focus on employment and employment readiness outcomes, it misses opportunities to think more comprehensively about the needs of adult learners beyond their economic needs.

Scholarship of the past decade recognizes the complex causes that drive ABE learners' progress. Becker Patterson and Paulson (2015) reviewed data released from the 2013 Programme for the International Assessment of Adult Competencies (PIAAC) Survey of Adult Skills. In looking at the PIAAC data, Becker Patterson and Paulson (2015) explored the complexity of experience and outcomes within $\mathrm{ABE}$ and suggested implications for "the workplace, formal and nonformal adult and continuing education, and policy makers" (p. 35). However, such complex analyses are rare as most funded studies provide evaluation of program efficacy. Rossi and Bunger (2018) studied GED students in New York State and found that despite intentions to do so, GED passers most often did not transition to post-secondary education. They concluded that, "If GED passers are not significantly more likely to enroll in college based on the usual array of demographic variables, then we should explore what actually drives this behavior" (Rossi \& Bunger, 2018, p. 19). Olsen (2014) explored the needs of youth into adulthood and concluded that learning how to apprehend new forms of learning, developing non-cognitive skills, and connecting learning to pragmatic experiences make the process of learning complex for these learners to make the transition.

Davis (2014b) concurs with Olsen's assessment of the complexity of the youth to adult transition and further explains that finding self-agency is critical for these learners to transition educationally. Employing ethnodrama to explicate the experiences of GED students, Davis (2014a) also shows that students' past experiences with school, their social positions within the educational system, life circumstances such as moving or pregnancy impacted their leaving school and influenced their decision to return to school. As a result, Davis argues for the inclusion of student voices in the development and implementation of adult basic education. Reynolds and Johnson (2014) suggest that the ABE classroom should be one that builds on the assets that learners bring to it by supporting four "pillars" that the authors borrow from Thompson and Cuseo: the individual, family, institution, and community. Becker (2011) suggests that learners' limited resources combined with a lack of college knowledge create a lack of cultural capital required to transition into successful education beyond basic skills. All these scholars show that merely setting a goal for transition and measuring that goal is an inadequate approach to address the complex needs that learners bring to adult basic education.

Rubenson (2006) offers a way to look at the evolution of the purpose of basic skills through the lens he uses to look at lifelong learning. While these are separate fields of adult learning, the evolution he describes of lifelong learning is instructive. He identifies three generations, the first of which was a humanistic approach that emphasized the ways in which education could support people's personal goals and their needs to exist within a complex society. He identifies the second generation of lifelong learning as the period that was a reaction to the 
challenging economic conditions of the 1980s that saw inflation, stagnant wages, and rising unemployment. The resulting purpose of lifelong learning became focused on the economic benefits of learning (i.e., employees as human capital, learning as a tool for employment). The third generation was a "softened" version of the economic purposes in the early 2000s as lifelong learning expanded on economic purposes and allowed for social purposes that assisted learners (and thus the society) succeed in a society and economy that is knowledge based.

The parallel to what has happened over the past 30 years in ABE makes Rubenson's description worth comparing to ABE's progress. This comparison suggests that the evolution has happened in reaction to economic forces, and while it has softened, that focus continues to drive policy and practice. While that is understandable, adults who enroll in $\mathrm{ABE}$ have much more complex needs in their lives than just addressing their economic and employment needs. Whether those needs are helping these adults learn about civic engagement, learn about the often-bewildering education system that their children navigate, or learn how to manage the complexity of the current financial system, their needs are complicated.

People who teach in and manage these programs know this complexity. They are constantly adapting and developing curricula and experiences to assist the students they serve with the complexity of their lives (e.g., Ozum 2012; Rendon, 1994). However, because people engaged with the practices of $\mathrm{ABE}$ focus on practical applications, they rarely affect larger policy discussions. The policy makers who allocate resources and create rules that measure the efficacy of practice rarely hear from teachers and program directors; and, if they do, it is in a controlled setting where practitioners are asked to show how what they do is successful - a systemic preservation that reinforces the status quo. Moreover, those of us involved in research often must conduct those studies for which we can find funding that is often provided by policy makers seeking to assess efficacy of what exists. By not examining the purposes for which ABE exists, and by not questioning the ways in which policies and practices are mandated, the system self-perpetuates.

A focus on transition out of basic skills is not wrong. It is important to value the economic importance of ensuring that basic skills students go beyond basic skills and find employment in family-wage jobs (Alamprese, 2005; Prince \& Jenkins, 2005). There are also clear societal benefits of having basic skills learners matriculate beyond basic skills (Strawn, 2007; Baum \& Payea, 2010). However, basic skills should be more than utilitarian pre-employment training. As Frerie (2013), Dewey (2012) and others have noted, education has the potential to allow learners to see the full possibilities in their lives. It cannot exist if it ignores learners' economic needs. However, basic skills also cannot succeed if it plays a zero-sum game where "transition to" exists at the expense of other purposes. In truth, as the Oregon Pathways project suggests, it is actually by addressing the needs of learners more holistically that "transition to" becomes successful(Alamprese, 2014). This is also corroborated in other studies with other populations (e.g., adults with special needs; see: Hughes, Johnson, Taga, 2018).

$\mathrm{ABE}$ must mature beyond the limitations of a softer economic purpose and address the complexity of needs that learners bring. That will happen only if those who develop and implement ABE participate in developing the policies that drive their practices. That also requires that policy makers seek and listen to the practitioners and academics who explore the fully complex needs of adults in these programs. 


\section{References}

Alamprese, J. A. (2005). Helping adult learners make the transition to postsecondary education. Washington, DC: U.S. Department of Education Office of Vocational and Adult Education.

Alamprese, J. A. (2014). Preparing for the future: Final report for Oregon Pathways for Adult Basic Skills Transition to Education and Work (OPABS). Salem, OR: Oregon Department of Community Colleges and Workforce Development.

American Institutes for Research. (2019). NRS History. Retrieved from https://www.nrsweb.org/about-us/ history

Bannon, J. L. (2016). Capitalizing on adult education: The economic imperative for literacy in 1960s federal policy discourse. College English, 78(4), 314-339.

Baum, S., Ma, J., \& Payea, K. (2010). Education pays 2010: The Benefits of higher education for individuals and society. New York, NY: College Board Advocacy and Policy Center.

Becker, L. A. (2011). Noncredit to credit transitioning matters for adult esl learners in a California community college. New Directions for Community Colleges, 155, 15-26.

Becker Patterson, M., \& Paulson, U. G. (2015). Adult transitions to learning in the USA: What do PIAAC survey results tell us? Washington, CD: American Institutes for Research.

Davis, C. A. (2014a). Unraveled, untold stories: An ethnodrama. Adult Education Quarterly, 64(3), 240259. doi: $10.1177 / 0741713614531067$

Davis, C. A. (2014b). Youths transitioning as adult learners. New Directions for Adult \& Continuing Education, 2014(143), 63-72. doi: 10.1002/ace.20105

Demetrion, G. (2005). Conflicting paradigms in adult literacy education: In quest of a U.S. democratic politics of literacy. New York, NY: Routledge.

Dewey, J. (2012). Democracy and education: An introduction to the philosophy of education [Kindle version]. Retrieved from Amazon.com
Freire, P. (2013). Education for social consciousness (2013 ed.). New York, NY: Bloomsbury Academic.

Hughes, B., Johnson, C., \& Taga, B. (2018). New Directions in Adult and Continuing Education: Support and Transitions for Adults with Special Needs (Vol. 2018, No. 160). Hanover, PA: Wiley.

Jenkins, D., Zeidenberg, M., \& Kienzl, G. (2009). Educational outcomes of I-BEST, Washington State Community and Technical College System 's integrated basic education and skills training program: Findings from a multivariate analysis. New York, NY: Community College Research Center, Teachers College, Columbia University.

Literacy Information and Communication System. (2019). College and career readiness standards for adult education. Retrieved from https://lincs.ed.gov/ professional-development/resource-collections/ profile-521

Olson, J. S. (2014). Transitions from formal education to the workplace. New Directions for Adult \& Continuing Education, 2014(143), 73-82. doi: 10.1002/ace.20106

Ozmun, C. D. (2012). Crossing the bridge: The role of lived experiences in shaping noncredit workforce education students' educational goals. Community College Enterprise, 18(1), 8-21.

Pimentel, S. (2013). College and career readiness standards for adult education. Berkeley, CA: U.S. Department of Education Office of Vocational and Adult Education.

Prince, D., \& Jenkins, D. (2005). Building pathways to success for low-skill adult students: Lessons for community college policy and practice from a statewide longitudinal tracking study. New York, NY: Community College Research Center Teachers College, Columbia University

Rendon, L. I. (1994). Validating culturally diverse students: Toward a new model of learning and student development. Innovative Higher Education, 19(1), 33-51. 
Reynolds, S., \& Johnson, J. (2014). Pillars of support: A functional asset-based framework for ABE learners. Journal of Research \& Practice for Adult Literacy, Secondary \& Basic Education, 3(3), 36-49.

Rossi, R. J., \& Bower, C. B. (2018). Passed to fail? Predicting the college enrollment of GED ${ }^{\circ}$ passers. Adult Education Quarterly, 68(1), 3-23. doi: $10.1177 / 0741713617721970$

Rubenson, K. (2006). The Nordic model of lifelong learning. Compare, 36(3), 327-341.

Stein, S. (2001). Equipped for the Future Content Standards: What adults need to know and be able to do in the 21st century. Washington, D.C.: National Institute for Literacy.

Sticht, T. G. (2008). The great literacy testing debacle in the United States. Reading Today, February/March, 21.

Strawn, J. (2007). Policies to promote adult education and promote literacy. Washington, DC: National Commission on Adult Literacy.
Taylor, J., \& Bragg, D. D. (2012). Participation and immediate outcomes of Illinois bridge programs. Champaign, IL: Office of Community College Research and Leadership. University of Illinois - Urbana Champaign.

U.S. Department of Education. (2016). Federal Register. (34 CFR Parts 461, 462, 463 et al). Washington, D.C.

U.S. Department of Education. (2019). Adult Education -Basic Grants to States. Retrieved March 12, 2019, from https:/www2.ed.gov/programs/adultedbasic/funding.html

U.S. Department of Education Office of Vocational and Adult Education. (2012). Promoting college and career readiness: Bridge programs for low-skill adults. Washington, DC.

Zeidenberg, M., Cho, S.-W., \& Jenkins, D. (2010). Washington State's Integrated Basic Education and Skills Training Program (I-BEST): New evidence of effectiveness. New York, NY: Community College Research Center, Teachers College, Columbia University. 